\title{
MIRROR ON THE WALL; Refleksivitas Keberpihakan Media Dalam Pemilihan Presiden Tahun 2014.
}

\author{
Fiandy Mauliansyah \\ Program Studi Ilmu Komunikasi, Universitas Teuku Umar \\ Email: Fiandymauliansyah@gmail.com
}

\begin{abstract}
This paper wants to examine how media bias in the political process in Indonesia especially in the context of the presidential election in 2014. The study found that in the present political news about the elections, the mass media over use to the theory of journalism, which is based on the values of fame ( prominency) or public figures (public figure) instead of human values (human interest) and public interest (signifcant). So the media often promote norm "zero-sum" in politics, as a part of the discipline of media coverage on the election. Media stuck to pit two or more presidential candidates by calculating their speed running after quantity of support, regardless of whether the support is achieved by means of political mobilization false or adequate education.
\end{abstract}

Keywords: Bias Political. Balancing Media. Media Coverage

\section{PENDAHULUAN}

Proses pemilihan presiden memang menjadi momentum penting bagi rakyat Indonesia. Mengetahui informasi tentang calon presiden dan wakil presiden mendatang menjadi hal yang sangat penting untuk menentukan pilihan. Media massa khususnya televisi merupakan alat terpopuler bagi manusia untuk mengakses kebutuhan informasi itu. Karena itu, tidak heran apabila masyarakat memilih tayangan di televisi untuk mengakses informasi tentang proses politik dalam Pilpres 2014. Besar harapan rakyat menaruh kepercayaan terhadap media untuk memberikan informasi yang layak, jujur, netral, dan berimbang. Namun, apa yang terjadi ketika media tidak dapat memberikan informasi yang layak, jujur, netral, dan tidak berimbang? Di era politik modern, hampir sebagian besar proses politik sesungguhnya merupakan politik yang termediakan. Artinya, perantara antara elite dan massa tidak lagi dominan dilakukan partai maupun kelompok politik, tetapi makin banyak diambil alih oleh media, terutama televisi. Abad baru politik saat ini memunculkan kelahiran tipe baru politisi dengan mengeksploitasi potensi media, terutama media yang dapat menampilkan suara dan gambar yaitu televisi.

Politisi berada dalam bisnis penciptaan keahlian dan penampilan personalitas yang ditelevisikan. Media televisi memiliki peranan besar dalam membentuk opini publik tentang siapa capres pilihannya. Sebab, televisi menyajikan gambar dan suara. Sehingga efek yang terbangun dari media televisi terhadap publik sangat besar berpengaruh dalam pembentukan opini publik. Sayangnya, saat ini Komisi Penyiaran Indonesia (KPI) tengah membahas untuk memberikan sanksi kepada lima media televisi yang dinilai tidak netral, yaitu TV One, Metro TV, RCTI, MNC TV, dan Global TV. Dalam keteranganya Ketua KPI Judhariksawan menilai bahwa kelima media tersebut tidak netral menjelang pemilihan presiden, yaitu tidak netral dalam menyiarkan kegiatan-kegiatan capres. Selain itu, porsi pemberitaan yang lebih banyak 
memberikan durasi penyiaran yang lebih panjang untuk pasangan capres-cawapres tertentu (Kompas, 2 Juni 2014). Dua stasiun televisi swasta yang konsen terhadap program berita, yaitu TV One dan Metro TV. Kedua televisi ini merupakan representasi produsen berita televisi di Indonesia. Kedua media televisi ini menjadi pilihan masyarakat dalam mengakses informasi tentang calon presiden dan proses demokratisasi di Tanah Air. Meskipun ketiga stasiun televisi tersebut menyiarkan program berita, namun program berita yang ditayangkan tidak sebanyak TV One dan Metro TV.

Dalam hal ini, sebenarnya pers berperan sangat penting dalam menentukan berkembang atau tidaknya demokrasi. Itu sebabnya, Edmund Burke tak segan menyebut pers sebagai pilar keempat demokrasi setelah eksekutif, legislatif, dan yudikatif. Hal itu merujuk pada empat peran ideal pers yang antara lain sebagai sumber informasi yang berimbang dan mendidik masyarakat (pendidikan politik), menjadi pengawas penguasa (watchdog) dalam menjalankan pemerintahan, sebagai penyambung lidah (mediator) publik dengan pemerintah, dan sebagai ruang advokasi publik.

Namun di sisi lain, keberadaan pers juga tak lekang dari kritik tajam. Hal ini disebabkan oleh (terkadang) adanya peran ganda yang dimainkan. Selain melakukan fungsi ideal seperti tertera di atas, pers kerap kali terjebak dan tak kuasa melawan kungkungan kapitalisme (baca pemilik modal). Bahkan dengan sinis McNair Brian (1995) pernah mengatakan, "Media bukanlah ranah yang netral dimana berbagai kepentingan kelompok akan mendapatkan perlakuan yang sama dan seimbang. Media justru bisa menjadi subyek yang mengkonstruksi realitas berdasarkan penafsiran dan definisinya sendiri untuk disebarkan kepada khalayak".

Melihat paradoks ini, tak mengherankan apabila kemudian Presiden SBY terus mengingatkan para pekerja pers agar tetap mawas diri. Menjelang Pemilu 2014, tentu kondisi politik nasional akan memanas. Itu sebabnya Presiden SBY sangat berharap pers bisa berlaku adil dan seimbang dalam memberikan infomasi kepada masyarakat. Pers diharapkan bisa memberikan pendidikan politik yang baik. Dalam konteks menghadapi Pilpres 2014, Presiden SBY mewanti-wanti kepada para awak pers agar semua kandidat yang akan maju menjadi capres pada pemilu 2014 bisa mendapat porsi pemberitaan yang sama di hadapan publik. Pertanyaanya, akan kah itu bisa terjadi?

\section{KAJIAN TEORITIK}

\section{Politik Media Saling Serang}

Ada hal yang menarik yang perlu dikaji tentang kedua media televisi ini (Metro TV dan TV One) pasca-ditetapkannya koalisi partai dan penetapan calon wakil presiden. Politik saling serang melalui media dapat kita rasakan di mana kedua media ini saling menyerang dan membuat citra positif dalam memberitakan capres pilihannya. Bagaimana TV One menyerang capres Jokowi dan sebaliknya Metro TV menyerang capres Prabowo. Misalkan pemakaian tagline berita ketika TV One sedang memberitakan tentang Prabowo diberi judul "Presiden Pilihan Rakyat" sedangkan Metro TV dengan judul "Presiden Pilihan Kita". Bayangkan dalam sehari publik disuguhkan program berita 5-6 program berita dan belum lagi setiap satu jam kedua stasiun televisi ini menampilkan program softnews yaitu headline news dan breaking news selalu menampilkan citra masing-masing capres pilihannya. Sudah menjadi rahasia 
umum siapa pemilik kedua televisi swasta ini. Aburizal Bakrie merupakan pemilik TV One yang juga notabene sebagai ketua umum Partai Golkar, dimana dalam hal ini Golkar berkoalisi dengan Partai Gerindra yang mendukung capres dan cawapres Prabowo-Hatta. Sedangkan Metro TV dimiliki oleh Surya Paloh yang notabene juga adalah sebagai ketua Partai Nasdem yang berkoalisi dengan PDIP mendukung Jokowi-Jusuf Kalla. Politik saling serang kedua pasangan capres yang difasilitasi kedua media menunjukan hal-hal negatif masing-masing capres yang dibahasakan melalui tim suksesnya. Hal yang subtansial untuk diinformasikan kepada publik tentang capres justru malah diabaikan. Jika demikian mak

Media justru lebih cenderung mengedepankan unsur konflik di antara kedua pasangan capres tersebut. Apa yang terjadi ketika kedua media televisi ini membangun frame masingmasing terhadap kedua pasangan capres-cawapres. Dalam konteks ini kita melihat bagaimana membangun mekanisme framing media. Seperti yang diungkapkan Agus Subdibyo, framing adalah metode penyajian realitas di mana kebenaran tidak diingkari secara total, tetapi dibelokkan secara halus, dengan memberikan sorotan terhadap aspek-aspek tertentu, dengan menggunakan istilah yang memiliki konotasi spesifik, dengan bantuan foto, karikatur, backsound, slow motion yang dilambatkan, dan beberapa ilustrasi lainya. Artinya, bagaimana framing dapat diartikan sebagai tindakan menyeleksi aspek realitas yang ada dalam visualisasi pada teks, kemudian membuat aspek realitas yang lebih menonjolkan dari aspek-aspek lain. Aspek lain ini misalkan gaya bahasa yang digunakan, variasi lain yang digunakan untuk menjabarkan skema interpretasinya sendiri, dan cenderung mendistribusikan retorika untuk meneguhkan keberpihakan atau kecenderungan tertentu. Ketika media dikendalikan oleh berbagai kepentingan ideologis di baliknya, ketimbang menjadi cermin realitas (mirror of reality), media sering dituduh sebagai perumus realitas (definer of reality) sesuai dengan ideologi yang melandasinya. Beroperasinya ideologi di balik media tidak dapat dipisahkan dari mekanisme ketersembunyian (invisibility) dan ketidaksadaran (unconsciousness), yang merupakan kondisi dari keberhasilan sebuah ideologi (Yasraf A Pilian, 2004). Artinya, sebuah ideologi itu menyusup dan menanamkan pengaruhnya lewat media secara tersembunyi (tidak terlihat dan halus), dan ia merubah pandangan setiap orang secara tidak sadar.

Hiperealitas media menciptakan model komunikasi (satu arah), yang didalamnya terbentuk massa sebagai mayoritas yang diam (the silent majorities), yaitu massa yang tidak mempunyai daya resistensi dan daya kritis terhadap tanda-tanda yang dikomunikasikan kepada mereka, oleh karena telah berbaurnya realitas-simulakrum, kebenaran-kepalsuan, faktarekayasa. Persoalan ideologis pada media muncul ketika apa yang disampaikan media (dunia representasi), tatkala dikaitkan dengan kenyataan sosial (dunia nyata), memunculkan berbagai problematika ideologis di dalam kehidupan sosial dan budaya. Pertanyaan-pertanyaan ideologis yang sering muncul megenai politik media adalah, misalnya: apakah media merupakan cermin atau refleksi dari realitas? Atau, apakah ia sebaliknya menjadi cermin dari separuh realitas dan menjadi topeng separuh realitas lainannya? Apakah media melukiskan realitas atau sebaliknya mendistorsi realitas. Pada akhirnya wacana politik berkembang ke arah politik citra (politic of image) atau politik simulakrum. Di dalam politik simulakrum, opini publik dibentuk oleh realitas (kebenaran dan fakta) yang disuguhkan oleh media, yang semuanya sesungguhnya tak lebih dari realitas artifisial, yang menyampaikan separuh kebenaran dan menyembunyikan separuh kebenaran lainnya. Akan tetapi, massa yang terperangkap di dalam simulakrum politik menyerap realitas-realitas yang disajikan media secara tidak kritis dan logis, sehingga realitas-realitas yang disajikan media secara tidak kritis 
dan logis, sehingga realitas-realitas melampaui tersebut kemudian membentuk opini dan sikap politik mereka, yang sesungguhnya telah terdistorsi oleh politik informasi. Pembentukan opini publik yang didapat melalui media televisi ini berpengaruh besar terhadap pilihan presiden pada pemilu mendatang. Apabila bisa berimbang, mungkin publik bisa menilai secara objektif. Namun, bagaimana kalau kedua media tersebut tidak dapat berimbang memberikan informasi kepada khalayak tentang track record capres_-bagaimana ideologi yang ditanamkan media terhadap khalayak tidak secara langsung, seperti yang diungkapkan sebelumnya ideologi melebur dalam tatanan publik yang tidak sadar ia masuk ke dalam pikiran kita yang menjadikan itu sebagai sebuah opini.

Akhirnya, masyarakat menjadi kurang kritis, bingung dan tidak mampu berpikir logis ketika ada campur tangan pihak tertentu dalam membentuk citra positif capres dan menyerang sisi negatif lawan capresnya. Media sebagai pilar keempat dalam demokrasi seharusnya dapat dengan tegas bisa memosisikan diri sebagai media yang tanpa intervensi. Media merupakan ruang publik dan sesuai dengan undang-undang frekuensi itu milik publik. Demi terciptanya persaingan media yang sehat sesuai dengan amanah Undang-Undang Nomor 32 Tahun 2002. Harapannya adalah media televisi perlu dengan tegas memproklamirkan" kembali siapa diri mereka, untuk apa mereka ada, dan apa yang harus mereka lakukan untuk mencerdaskan masyarakat. Mereka perlu menunjukkan kembali eksistensi diri mereka. Semua yang mereka lakukan ini, menurut jurnalisme, berorientasi pada usaha membangun media yang utuh dan mengajak masyarakat untuk membangun sistem demokrasi yang sehat di republik yang kita cintai.

\section{Peran Media dalam Pemilu}

Salah satu fungsi sentral media massa di ruang publik menurut Dennis McQuail (1994) adalah fungsi korelasi sosial (social correlation). Melalui berita dan opini yang dimuat secara reguler, media memandu public menghubungkan berbagai realitas yang sebelumnya terpisah oleh factor geografi dan psikografi, menjadi satu rangkaian yang bisa diikuti dan dipahami secara mudah. Kekuatan rnedia dalam melakukan framing atas sebuah teks dan fakta memandu publik mengkorelasikannya ke dalam konteks ekonomi, sosial politik dan budaya pada kurun waktu tertentu (McQuail, 1994).

Saat iklim politik transisional yang kini melanda Indonesia, media kerap menjadi rujukan instan bagi pensikapan publik atas fenomena sosial tertentu akibat krisis komunikasi langsung mereka dengan pejabat publik. Media juga dapat menjadi subjek yang memanipulasi pernyataan atau peristiwa politik karena tekanan kepentingan ekonomi dan politik pemilik atau pengelolanya. Dalam iklim politik yang transisional, terdapat perilaku feodalistik media dalam bentuk pemberian ruang ekspresi lebih pada tokoh publik (extra ordinary people), opinion leader ketimbang kalangan biasa dalam masyarakat. Para pemimpin politik ditempatkan sebagai subyek aktif produsen informasi dan isu-isu yang selalu bisa dikorelasikan secara makro dan konstituennya sebagai obyek yang menerima begifu saja arus informasi yang topdown. Menurut Kepala Departemen Jurnalistik New York University Jay Rosen dalam tradisi jurnalisme politik, media adalah pemain (player), subjek aktif di ruang publik bukan sekedar medium atau alat yang dikendalikan pihak diluar pengelola media itu (Rosen, 2004).

Sebagai pemain yang berpengaruh, menurut pemikir politik Thomas Meyer, ada tiga dimensi relasi antara media dan polittk. Pertama, media dapat menjadi ruang publik bagi 
terjadinya interaksi politik, ikut mempengaruhi pembentukan sistem komunikasi politik di kalangan public (pembentukan karakter dan agenda politik berlangsung secara terbuka. Kedua, media tidak hanya menjadi cermin dari kehidupan politi tetapi melakukan generalisasi realitas politik, mengkonstruksi realitas politik sebagai sesuatu yang bersifat kompleks dan mengundang antusiasme respon publik. Ketiga, konstruksi realitas media atas dunia politik itu secara positif akan memperkuat komitmen pencapaian tujuan politik ideal dari partai politik atau politisi dan kontrol publik yang tajam atas proses itu (Meyer,2002). Sayangnya illustrasi relasi media dan politik versi Meyer ini terlampau ideal dan mengalami banyak kendala kultural dan struktural ketika diterapkan.

Pakar jurnalisme dan Ketua Committee of Concerned lournalists Bill Kovach saat peluncuran buku Sembilan Elemen Jurnalisme (2003) mengemukakan jurnalisme dan demokrasi tumbuh bersama-sama. Demokrasi tidak akan eksis tanpa jurnalisme politik yang baik. Jurnalisme gosip, rumor, jumalisme yang bercampur dengan hiburan, atau jurnalisme yang menjadi propaganda politik akan meracuni demokrasi (Kovack, 2001). Dalam Pemilu, jurnalisme mesti menyajikan fakta-fakta dan informasi independen tentang peristiwa dan isuisu yang akan jadi referensi bagi masyarakat dalam membuat keputusan. Kovach mengingatkan bahwa tujuan paling penting bagi jurnalisme adalah menyediakan informasi yang dibutuhkan warga agar mereka bisa hidup merdeka dan mengatur diri sendiri. Untuk itu independensi media sangatlah penting. Independen dari otoritas politik, otoritas sosial atau bisnis, dan tidak ada bias personal. Loyalitas jumalis semestinya bukan loyalitas pada pemilik media tetapi loyalitas kepada warga negara.

Kovack merekomendasikan model watchdog journalism atau anjing penjaga yang secara sederhana menempatkan media dan jumalis sebagai the monitor of power bukan agent of power. Dalam konteks penerapan jurnalisme politik pada institusi media komersial, kredibilitas media dipengaruhi kemampuannya mengimbangi pesan-pesan periklanan politik yang diterimanya dengan muatan jurnalisme politik yang kritis terhadap kesalahan yang dilakukan pemasang iklan itu. Hal itu dapat dilakukan, antara lain dengan poling rutin media untuk menyiarkan visi, misi, dan program partai/capres d.an cawapres dengan waktu/ruang yang memadai sehingga dapat membantu pemlih menseleksi informasi politik yang dibutuhkan. Media massa baik cetak maupun elektronik idealnya tidak hanya "panen" iklan politik, tetapi marak dengan berita-berita politik yang tajam. Peran watchdog dalam media secara sederhana adalah peran kritis membuat manajemen dan proses eksekusi kebijakan dari kekuasaan berlangsung transparan, membuat publik mengetahui persis akibat yang akan mereka terima dari kebijakan penguasa itu.

Kenyataan membuktikan, bagian besar iklan politik, sebagaimana jtgu berita politik, ditujukan kepada khalayak di akar rumput. Keduanya seharusnya dibangun dan dikembangkan lebih informative dan etis. Hal itu penting karena segmen khalayak ini kurang memiliki akses informasi sehingga mereka amat rentan terhadap gencarnya pesan-pesan periklanan sesat. Media perlu terus diingatkan akan rumusan pasal 6 UU No. 40/1999 tentang Pers yang menyebutkan: Pers nasional melaksanakan peranannya: a. memenuhi hak masyarakat untuk mengetahui; b. menegakkan nilai-nilai dasar demokrasi, mendorong terwujudnya supremasi hukum, dan Hak Asasi Manusia, serta menghormat kebhinnekaan; c. mengembangkan pendapat umum berdasarkan informasi yang tepat, akurat dan benar; d. melakukan pengawasary kritik, koreksi, dan saran terhadap hal-hal yang berkaitan dengan kepentingan umum; e. memperjuangkan keadilan dan kebenaran. 
Secara normatif, jumalis Tim Russerf Jody Wilgoren and Howard Fineman dalam Kovach (2001) menyarankan perlunya jurnalis yang berkecimpung dalam liputan politik untuk selalu bertanya: siapa saya? Di mana sekarang posisi saya dan'di mana posisi seharusnya? Apa saja yang telah dan akan saya kerjakan dalam lingkaran politik? Apa sikap politik saya terhadap suatu peristiwa atau figr. kandidat? |awaban yang harus selalu keluar dalam ucapan dan tindakan adalah We're professionals who haae no partisan role. We are neutral tozoard all parties, factions, candidates. We're on the public's side, We supply uital neurs, a context for understanding it, analysis and interpretation where needed.

Menurut Russert dalam Kovach (2001), dua tujuan utama jurnalisme politik adalah menempatkan kepentingan pihak yang berkuasa agar tetap berkorelasi dan bertanggungjawab kepada kepentingan publik (to hold powerful interests accountable to the public interest), dan menjelaskan pada pemilih bagaimana mengaitkan harapan ketika menunaikan hak sebagai warga negara dengan apa yang harus dikerjakan oleh pemerintahnya (to explain to aoters how to connect how they aote with uthat their government should do). Melalui jurnalisme, media dan jurnalis menjadi salah satu dari tiga aktor strategis.

\section{Keberpihakan Media}

Jurnalisme politik (political journalism), dalam perspektif ekonomi politik meminjam istilah Noam Chomsky pada awalnya dikenal sebagai jurnalisme propaganda, yaitu praktek jurnalisme "siap saji" (fast food) mewadahi kepentingan dominan yang pada umumnya dikontrol oleh uang dan kekuasaan pejabat negara (controlledby the moneyed and power elite). Dalam buku yang ditulis bersama dengan Edward Herman, Manufacturing Consent: The Political Economy of the Mass Media, Noam Chomsky menyebutkan bahwa the "Propaganda Model" of the power elite who control the media and use forms of censure to keep unzaanted ideas out of the popular consciousness. Model propaganda adalah model posisi media yang dikontrol kekuatan elit dan media melakukan sensor internal untuk memproteksi masuknya ide-ide populis yang berbasis kesadaran publik. Dalam jurnalisme propaganda, media tidak menganut semangat memberikan pendidikan politik yang sehat (voters and electoral education). Media membiarkan diri menjadi political public relations para kandidat (Herman \& Chomsky, 1991).

Menurut Noam Chomsky, kecenderungan media menjadi propaganda terutama di musim kompetisi pemilihan presiden merupakan akibat dari beragam aspek. Pertama, terkonsentrasinya pemilikan media pada sekelompok elit kekuatan ekonomi, sejumlah konglomerat yang secara keamanan bisnis (business safety) masih sangat tergantung pada kekuatan politik yang sedang atau akan berkuasa (Chomsky, 1991). Penguasaan atas media utama seperti televisi komersial oleh pengusaha bertipe demikian akan menempatkan media itu sebagai alat tawar politik mereka dengan calon penguasa yang dinilai optimis memenangkan pertarungan politik. Imbalannya, media itu akan dijadikan ruang promosi dan pembentukan opini public memenangkan kandidat yang bersedia memberi kompensasi keamanan mengelola korporasi media mereka di masa mendatang. Baik di Indonesia maupun di sejumlah negara lain, pemilikan media (media ownership) terkonsentrasi pada sekelompok pengusaha yang tidak independen terhadap pengaruh politik bahkan kelahirannya secara historis diberi gizi oleh rezim otoriter yang berkuasa, bukan oleh kehendak publik. Kedua, orientasi komersial yang terlampau berlebihan, penggunaan iklan sebagai sumber utama 
pendapatan (primary source of income) bisnis media. Musim pemilihan umum sebagaimana musim kompetisi sepak bola atau olah raga lainnya ibarat musim panen bagi

Media massa untuk meraup keuntungan dari iklan politik yang dipasok oleh partai politik atau kandidat presiden-wakil presiden. Perputaran uang yang mencapai ratusan milyar rupiah jelas menggiurkan, apalagi bagi pengusaha pemula yang masih harus berjuang keras meraih posisi am:rn dalam bisnisnya. Situasi ini didukung oleh regulasi iklan politik yang longgar, yang membuka konspirasi pemilik media dengan para politisi dalam terorisasi publik melalui iklan-iklan yang pesan politiknya dangkal. Lembaga pengawas korupsi Transparansi Internasional memperkirakan dana politik yang dibelanjakan untuk memasang iklan di media satu bulan masa kampanye Pemilu di Indonesia (1 Maret-l April 2004) sebesar Rp 54 miliar total untuk 24 partai. Lebih separuhnya untuk televisi, disusul media cetak. Radio sekitar Rp 322 juta. Pengiklan terbesar adalah PDI-P Rp 50 miliar dan partai Golongan Karya 36 miliar (Luwarso, 2004). Menurut Robert McChesney, jurnalisme politik yang pro kekuatan kapitalis merupakan anak kandung dari jurnalisme politik partisan di masa-masa sebelumnya. ]ika jumalisme politik partisan secara terbuka mengungkapkan identitas keberpihakan politiknya kepada politisi atau partai politik tertentu, maka jumalisme politik yang pro kapitalis lebih halus dalam memainkan keberpihakannya kepada kekuatan politik yang menopang rutinitas media sebagai institusi bisnis (McChesney, 1998).

Ketika jurnalisme telah diintervensi kepentingan komersial pemilik media, maka kita tidak akan pernah menemukan suatu proses pemberitaan yang benar-benar bersifat netral. Ideologi di balik jurnalisme profesional tidak lain sebagai bentuk penghambaan terhadap pemilik modal dan pemasang iklan dalam suatu sistem media. Isi bukan ditujukan bagi kepentingan pembaca atau pemirsa, tetapi justru lebih diupayakan bagi kepuasan kedua pemodal dan pemasang iklan yang notabene elit politik. "Obyektifitas" peliputan Pemilu 2004 adalah penerimaan secara terang-terangan terhadap keinginan politisi dan partai politik dalam upaya mengejar target politiknya. Jurnalisme profesional telah menjadi suatu aktifitas kering yang kehilangan semangat independensi. Ketiga, tradisi jurnalistik yang masih konvensional, menggantungkan sumber informasinya (sourcing mass media news) pada tiga lingkaran elit dalam masyarakat, yaitu kalangan bisnis, pemerintah dan pakar, akademis atau peneliti. Beritaberita yang digali berbasis sumber informasi dari kalangan lapisan bawah (grassroot people) jarang mendapat tempat yang layak sebagai pembuka perdebatan apalagi menjadi berita utama (headline). Mereka kerapkali ditempatkan sebagai pelengkap dari sebuah laporan melalui tayangan gambar yang menyentuh, penanggap pernyataan politisi atau pejabat publik yang dikutip pendek, sebagai sumber data angka atau visual untuk memberi kesan kontras pada kebijakan pembangunan.

Dalam menyajikan berita politik seputar Pemilu, media massa terlampau banyak menganut teori jurnalistik yang bertumpu pada nilai-nilai keterkenalan (prominency) atau tokoh publik (public figure) bukan nilai-nilai kemanusiaan (human interest) dan kepentingan publik (signifcant). Keempat, mengedepankan norma "kalah menang" dalam politik, sebagai bagian dari disiplin peliputan media atas pelaksanaan Pemilu. Media terjebak untuk mengadu dua atau lebih kandidat presiden dengan menghitung kecepatan mereka berlari mengejar kuantitas dukungan, tanpa peduli apakah dukungan itu diraih dengan cara mobilisasi semu atau pendidikan politik yang memadai. Situasi ini mirip ajang pacuan kuda (horserace) ketika media lebih fokus pada laporan siapa yang menang (who's leading) dan siapa yang kalah (who's losing out). Perang wacana yang bersifat menyerang satu sama lain antarkandidat ditempatkan 
sebagai menu utama, ketimbang pertarungan gagasan genial untuk mengatasi masalah mendasar bangsa. Menjelang hari pemungutan suara, media lebih banyak menampilkan survei peringkat kandidaf prediksi siapa memang dan kalah, pidato atau pemyataan informal kandidat (candidate's speeches). Media mulai mengurangi sajiannya seputar kualifikasi kandidat latarbelakang politik dan pandangan pemilih atas mereka.

Dalam praktek jurnalisme politik di negara berkembang seperti Indonesia, jarang ditemukan berita dan opini yang mendalam atau bersifat analitis, melibatkan semua sudut pandang dalam masyarakat. Kebanyakan realitas media lebih tampak sebagai sebuah sajian spekulasi-spekulasi, korelasi-korelasi instrumental, bukan korelasi substansial. Karena akses penguasaan informasi dan pengendalian jurnalis yang hanya lebih terpusat pada lingkaran elit sumber di masyarakat, media utama (mainstereem) kerapkali lebih berperan sebagai alat propaganda kelompok-kelompok kepentingan dominan dalam masyarakat seperti partai politik atau politisi yang berkuasa.

Sekarang ini, apa yang disajikan dalam beberapa media televise di Indonesia menjelang pilpres 2014 ini, bukanlah sebuah peristiwa unik. Para peneliti bidang media sudah lama membicarakan tentang bagaimana sebuah berita media dikonstruksi, dibingkai (Entman, 1993; Norris dkk, 2004; Pan \& Kosicki, 1993; Reese, 2001; Callaghan \&Schennel, 2005) dikemas dan dipabrikasi oleh media dan para pekerjanya (Koch, 1990; Herman \& Chomsky, 2002). Disamping itu media juga bisa melakukan penonjolan suatu isu sehingga menjadi berita yang selalu muncul di ruang-ruang penting media cetak atau diwaktu siaran utama televise. media menyeting agenda media (McComb and Show, 1993). Media memilih menyaring, dan menentukan berbagai informasi untuk kemudian disebarkan kepada public. Media melakukan proses penyaringan berita (Shoemaker, 1991), sehingga tidak semua realitas sosial, yang ada dalam kenyataannya, tidak pernah termuat dalam media massa atau pers. Dalam proses gatekeeping ini ada banyak factor yang mempengaruhinya. Shoemaker menyebut ada sejumlah saringan ideology media, profesionalisme dan nilai-nilai wartawan dan sebagainya. Herman dan Chomsky (2002) mengungkapkan media massa di Amerika dengan gencar memberitakan Perang Vietnam, sebaliknya tidak memberi perhatian memadai terhadap peristiwa invasi Indonesia ke Timor-Timur.

\section{Media Sebagai Watchdog}

Salah satu fungsi penting yang dijalankan oleh pers dalam masyarakat demokratis adalah pers sebagai lembaga yang menjalankan fungsi pengawasan terhadap berbagai lembaga yang memiliki kekuasaan besar dalam masyarakat. Pers atau media massa menjalankan fungsi sebagai anjing penjaga (watchdog) yang melakukan pengawasan terhadap berbagai lembaga sosial, politik maupun lembaga-lembaga ekonomis yang jika tidak diawasi dapat melakukan monopoli kekuasaan politik, budaya maupun ekonomi. Sebagai watchdog (anjing penjaga), media berfungsi untuk mengawasi mereka yang memiliki kekuasaan baik dalam bidang politik (pemerintah), organisasi nirlaba maupun dalam sektor swasta. Pengawasan terhadap mereka yang memiliki kekuasaan perlu dilakukan agar tidak terjadi penyalahgunaan kekuasaan (abuse of power).

Dalam kaitan ini, pers dianggap sebagai kekuatan keempat setelah legislatif, eksekutif dan yudikatif, yang dianggap sebagai salah satu kekuatan untuk menjamin adanya check and balances dari berbagai kekuasaan yang ada. Dalam peranan yang demikian ini, pers harus 
mampu melahirkan laporan-laporan investigatif untuk menampilkan berbagai penyelewengan kekuasaan yang berlangsung dalam berbagai lembaga yang ada. Pers sebagai watchdog menjadi semakin penting, terutama di negara-negara yang sedang mengalami proses transisi menuju demokrasi, termasuk Indonesia.

Dalam negara yang berada dalam massa transisi, terdapat masalah-masalah akut pembawaan pemerintahan otoriter seperti korupsi yang sistemik, pelanggaran HAM, lemahnya penegakan hukum, kolusi pengusaha dan penguasa, aparat pemerintahan yang tak becus dan berbagai masalah akut lainnya. Media diharapkan dapat menjadi bagian dari pengawasan terhadap proses transisi ini sehingga mampu mendorong masyarakat untuk melihat sistem politik yang demokratis adalah pilihan yang terbaik.

Konsep anjing penjaga ini berakar pada gagasan liberal klasik tentang hubungan kekuasaan antara pemerintah dan masyarakat dalam sebuah negara demokratis. Lebih jauh gagasan ini muncul berkaitan dengan gagasan tentang the fourth estate yang dikemukakan oleh Endmund Burke yang menenmpatkan pers sebagai kekuatan keempat di samping tiga pilar penting demokrasi yakni legislatif, eksekutif dan yudikatif.

Sebagai kekuatan keempat media atau pers menjalankan peran sebagai forum untuk diskusi dan melakukan penyelidikan dan pengawasan terhadap berbagai kekuasaan, terutama yang cendrung absolut atau menjadi monopolitsik. Jika pada awalnya, pengawasan yang dilakukan oleh media semata-mata tertuju kepada kekuasan politik, dalam perkembangannya, pengawasan bisa juga dilakukan terhadap berbagai bentuk kekuasaan dalam masyarakat, termasuk misalnya kekuasan bisnis atau ekonomis atau bahkan terhadap berbagai kekuatan sosial seperti kelompok keagamaan yang cenderung melakukan pemaksanaan dengan menggunakan kekerasan dalam menyelesaikan berbagai masalah.

Untuk itu, para pekerja pers dituntut agar dapat melakukan peliputan bukan saja yang berupa peristiwa-peristiwa sesaat dalam berbagai bidang kehidupan yang seringkali hanya menampilkan peristiwa-peristiwa yang bersifat permukaan, tetapi juga membuat laporan yang lebih mendalam tentang berbagai kehidupan para pemegang kekuasaan baik politik, ekonomi maupun kekuatan sosial budaya.

Peranan pers sebagai watchdog biasanya dijalankan melalui peliputan investigatif (investigative reporting) terhadap bagaimana sebuah kekuasaan dijalankan. Dengan demikian, pers akan mampu memberi informasi yang berbeda dengan informasi yang mungkin sudah 'dimanage' oleh para pemegang kekuasaan untuk menjaga citra/image mereka.

Saat ini, kemajuan dalam bidang kehumasan dan pemasaran serta munculnya konsultan politik pencitraan telah dimanfaatkan dengan sangat baik oleh pemegang kekuasaan untuk memanage setiap peristiwa sedemikian rupa sehingga mereka selalu 'tampak baik' di dalam media massa. Jika laporan-laporan yang demikian menjadi isi media massa/pers, tentu pendidikan untuk khalayak oleh media massa sulit diharapkan terjadi. Yang terjadi justru usaha untuk memperdaya warga negara melalui manipulasi laporan dalam media. Melalui liputan investigatif yang dilakukan media massa sebagai pengejawantahan peran sebagai watchdog, media mampu mempengaruhi bagaimana sebuah kekuasaan bisa diarahkan untuk menjadi lebih baik, adil dan membawa kemaslahatan bagi masyarakat. Protess dkk (seperti dikutip Coronel dalam makalahnya The Media as Watchdog untuk Workshop Harvard-World 
Bank 29-30 Mei 2008, di Harvard Kennedy School of Government), mengindentifikasi tiga dampak yang dapat dihasilkan dari pelaksanaan peranan pers sebagai watchdog ini.

Pertama, dampak yang dikategorikan sebagai 'deliberative' yaitu adanya dampak pada terbangunnya kemauan (terutama) pemerintah untuk mendiskusikan berbagai masalah dan solusinya. Kedua, dampak individual, yakni ketika para individu yang melakukan kesalahan mendapat sanksi sampai pada tingkat pemecatan atau pemakzulan dari jabatan ketika ini dilakukan oleh seorang pejabat bahkan sampai pada level Presiden, semisal Estrada di Filipina. Ketiga, dampak substantif, ketika terjadi perubahan-perubahan kebijakan, peraturan, prosedur bahkan kelembagaan pemerintah sebagai hasil dari adanya investigatif reporting.

Persoalannya, pers sebagai anjing penjaga saat ini justru sedang dibelit banyak masalah dan kendala, sehingga perannya sebagai anjing penjaga menjadi lemah. Meminjam ungkapan James Curran, saat ini ada kecenderungan anjing penjaga di bawah peliharaan para pemodal cenderung tertidur lelap, private watchdogs sleep.' Atau kalau diinterpretasi ulang, anjing penjaga yang sudah dipelihara para majikan pemilik modal atau para juragan sangat sulit untuk diharapkan dapat menjalankan fungsinya sebagai anjing pengawas yang selalu awas terhadap para penguasa dalam tiga dimensi kehidupan tadi.

Pers sebagai watchdog dalam kenyataan sekarang sudah mulai diikat kakinya dan dijinakkan gonggongannya. Betapapun, anjing biasanya sangat paham dengan tuannya. Dia tak akan menggonggong apalagi menggigit tuannya, walau mungkin tuannya melakukan tindakan yang mencurigakan. Dia hanya menggonggong orang asing yang tidak begitu dikenalnya.

Ibarat anjing, pers juga dapat digunakan oleh para pemilik media untuk menjadi pengawas untuk lawan politik, lawan bisnis sehingga ada media yang gencar mengolah suatu isu, tetapi membiarkan isu lain. Ada isu yang diblow-up dan ada isu yang sengaja tidak diberikan perhatian yang memadai. Pers akhirnya melupakan tugas yang lebih penting untuk menyalak pada setiap bentuk penyalahgunaan kekuasaan yang ada. Ini terjadi mengingat dalam kehidupan pers saat ini sudah terjadi tumpang tindih dalam kepemilikan. Pers sudah mulai dimiliki oleh pengusaha yang juga sekaligus terjun sebagai politisi. Sebagian dari mereka sadar dengan kekuatan media yang dapat dimanfaatkan untuk meraih keuntungan politis. Dalam keadaan demikian, sangat sulit bisa diharap media massa dapat menjadi anjing penjaga yang galak terhadap kekuasaaan.

Saat ini banyak juga pers yang diharapkan berfungsi sebagai watchdog telah dipelihara oleh orang atau lembaga yang harus digonggongnya. Pada level kelembagaan, dapat disaksikan kecenderungan terjadinya pemusatan atau penguasaan media media oleh para pemilik modal yang kemudian juga terjun dalam politik. Ini menyebabkan pers menjadi serba ragu dalam melakukan pengawasan.

Pada level praktek jurnalistik, masih dijumpai wartawan-wartawan yang menggunakan kewartawanannya untuk melakukan pemerasan atau hanya mencari pendapatan besar tanpa mampu menjalankan fungsi kewartawanan sebagaimana mestinya yakni mengungkap berbagai realitas sosial yang merugikan kehidupan masyarakat. Masih cukup banyak wartawan amplop atau bodrex yang justru dapat melemahkan peranan pers sebagai watchdog. Sebenarnya, jika pers mampu menjalankan peranannya sebagai anjing pengawas dengan baik, banyak penyalahgunaan kekuasaan yang terjadi dapat dicegah dan kehidupan berbangsa dan bernegara 
bisa lebih baik karena para pemilik kekuasaan dapat menjalankan kekuasaannya demi untuk kepentingan masyarakat.

\section{KESIMPULAN}

Untuk membangun demokrasi di Indonesia, media jangan sampai dipolitisasi, memelintir kebenaran. Mereka bekerja mengkonstruksi peristiwa di masyarakat untuk membentuk opini masyarakat yang sehat. Berbagai peristiwa itu dipotret untuk diletakkan pada frame dengan aneka sudut pandang dan warna. Namun, media menampilkan realitas yang diinginkan dan menyingkirkan realitas yang tidak disukai atau menyamarkannya. Dari situ terlihat untuk kepentingan siapa berita tersebut ditampilkan. Meski demikian, menurut survei Indo Barometer, tingkat kepercayaan masyarakat terhadap media masih mencapai 77 persen dibanding kepercayaan kepada pemerintah yang hanya 47 persen.

Hal itu menunjukkan besarnya peran pers dalam kehidupan masyarakat. Perilaku media yang menyimpang dari peran sebagai penjaga kebenaran dan pengawal demokrasi memang memprihatinkan. Banyak pengalaman dari pihak yang mendapat perlakuan yang kurang baik dari media. Keberpihakan kepada salah satu golongan dan menyerang yang lain sesungguhnya sudah mencederai profesi awak media.Hal itu menunjukkan besarnya peran pers dalam kehidupan masyarakat. Perilaku media yang menyimpang dari peran sebagai penjaga kebenaran dan pengawal demokrasi memang memprihatinkan. Banyak pengalaman dari pihak yang mendapat perlakuan yang kurang baik dari media. Keberpihakan kepada salah satu golongan dan menyerang yang lain sesungguhnya sudah mencederai profesi awak media.

Ketua Dewan Pers Bagir Manan mengingatkan bahwa media akan terhormat bila mampu menjaga kebebasannya sebagai pelayan masyarakat yang dipercaya. Media harus berprinsip hukum, mengembangkan demokrasi, nilai-nilai kemanusiaan, serta berdisiplin dan berkode etik (konvensi media massa di Kupang, 2011). Namun, pelanggaran kode etik melalui keberpihakan akan semakin meningkat sejalan dengan semakin panasnya suhu politik.

Ada dua kelompok politik yang menggunakan media sebagai ajang kampanye. Pertama, politisi yang harus membayar media untuk bisa menyampaikan pandangan politiknya kepada khalayak alias transaksi komersial iklan. Kedua, politisi yang merangkap sebagai pemilik media. Ada tren politisi yang berperan ganda sebagai pemilik media. Sebagai pemilik, tentu saja mereka bisa melakukan apa saja sesuai dengan keinginan mengunggulkan kelompoknya dan merendahkan kelompok lain.

Masyarakat bisa menjadi pengawas dan pemantau pers dengan jalan memantau serta melaporkan analisis mengenai pelanggaran hukum dan kekeliruan teknis pemberitaan yang dilakukan melalui pers. Hal itu bisa dilakukan dengan membentuk lembaga pemantau media (media watch). Media watch tidak bertujuan untuk menghambat media, tapi justru menyelamatkan dari kehancuran karena ditinggal khalayak. Keberpihakan politis media memang bisa menguntungkan dan memabukkan, tapi hanya temporer. Masyarakat memiliki peran strategis untuk menempatkan media pada posisinya sebagai pembawa kebenaran sekaligus mengawasinya. Lazimnya, media disebut anjing penjaga, watchdog.

Sebagai anjing penjaga, tuan sejatinya adalah masyarakat. Media harus menyalak keras bila menemukan hal yang tidak benar dan mengganggu masyarakat. Jadilah anjing bulldog atau 
doberman yang galak dan menggigit siapa pun yang layak digigit. Jangan jadi anjing pudel yang lucu untuk dimain-mainkan.

\section{DAFTAR PUSTAKA}

Andersery Robin ed. (2000). Critical Studies in Media Commercialism. London: Oxford University Press

Herman, Edward S. dan Noam Chomsky. (1992). Manufacturing Consent, The Political Economy of The Mass Media. New York: Pantheon Books.

Jurnalisme Propaganda dan Gosip Meracuni Demokrasi. Kompas Online, Kamis, Hal 1 Desember 2003

Kovack, Bill (2001). 9 Elements of lournalism. New York: The Rivers Press.

Luwarso, Lukas, ed. (2004). Media dan Pemilu 2004. Jakarta: Koalisi Media Untuk Pemilu Bebas dan Adil

Macmanus, John H. (1994). Market Driaen lournalism. London: Sage Publications

Mariani, Evi. (2001). 'Harian Rakjat Mengecam Resep jumalisme "orang Menggigit Anjing."' Pantau II No. 15 ]uli 2009

Masduki. (2004). 'Menyoal Fatwa Haram Presiden Perempuan.' Newsletter LP3Y, edisi 73 Mei.

McChesney, Robert (1998). Konglomerasi Media Massa dan Ancaman Terhadap Demokrasi. (terjemahan oleh Andi Achdian). Jakarta: Aliansi Jurnalis Independen.

McChesney, Robert. (1999). Rich Media, Poor Democracy: Communication Politics in Dubious Times. Illinois: University of Illinois Press.

McQuail, Denis (1994). Mass Communication Theory, Third Edition. London: Sage Publications

Meyer, Thomas (2002). Media DemouaW, How The Media Colonizt Politics. London: Polity Press

Nelson, Michael (ed). (2004). The Elections of 2004. Washington DC: Congressional Quarterly

Shoemaker, Pamela J. dan Reese, Stephen D. (1991)- Mediating the Message. Theories of Influences on Mass Media Content. New York: Longman Publishing

Undang-Undang Republik Indonesia No. 40 Tahun 1999 Tentang Pers 